Counting or measuring the stomata in situ on the leaf is possible with a few plants, notably Begonia coccinea, Chrysanthemum frutescens, Fuchsia speciosa, Impatiens Sultani, Primula obconica, Pelargonium zonale, Tradescantia zebrina, and Vicia Faba. In some others the condition of the pore can thus be observed, though the outlines of the guard cells are not clear: this is true in Senecio Petasitis, Helianthus annuus, Cyclamen latifolium, Coleus Blumei, Cestrum elegans, and Phaseolus vulgaris.

Marked variations in number and size of stomata occur, not only in different varieties of the same species, but in the same varieties grown under different external conditions. So far as my observation goes, however, the variation is greater in number than in size. Furthermore, while in most leaves the stomata are fairly evenly distributed over the surfaces containing them, in some, especially in oblong leaves (e. g., Fuchsia speciosa, Helianthus annuus, and Impatiens Sultani), the stomata are much more numerous near the base than near the tip (more than twice as many), and near the midrib than near the margin. For this reason very different figures might be given for the same leaf by different observers.

The opening and closing of the stomata of greenhouse plants is correlated closely with the time of day, and secondarily with the weather. As already noted, they are, as a rule, as wide open as they can be about ro A. M. -this, of course, in well-watered plants. In favorable weather they remain wide open until about 2.30 P. M., when they begin to close, and they are mostly completely closed by 5 P. M., though some may remain open until 6. On hot days in the spring they may close as early as I2 M., probably because of incipient wilting of the leaf. If the stomata are closed by wilting, they may be made to open, partially at least, by immersion of the leaf in water.

The best plants for general laboratory study, taking account of ease of removing the epidermis, size and clearness of stomata, and commonness of occurrence in greenhouses, are, in order of excellence, Chrysanthemum frutescens, Tradescantia zebrina, Pelargonium zonale, Fuchsia speciosa, Helianthus annuus, and Vicia Faba.-SOPHIA H. EcKerson, Smith College, Northampton, Mass.

\title{
THE ABSORPTIVE POWER OF A CULTIVATED SOIL
}

\section{(WITH THREE FIGURES)}

In the winter of 1908 we undertook a study of the absorptive power of a certain soil from one of the fields of the Michigan Agricultural College. In addition to the purely analytical methods which have been exclusively employed up to the present time in investigations of this kind, it was decided 
to approach the problem in a somewhat different way. If the absorptive power of the soil is a factor of real importance, so far as plant life is concerned, it would be reasonable to expect that a concentration of a given salt solution which has proved to be detrimental for a given kind of plant when grown in soil extract would be beneficial or at least do no harm to the same kind of plant when grown in the soil itself.

With this idea in mind, we undertook ( $\mathrm{I}$ ) to determine the maximum tolerance of wheat seedlings to concentrations of certain salts when grown in soil extract to which known quantities of the salt in question were added; (2) to grow the same kind of plants in paraffined wire baskets, ${ }^{I}$ using the

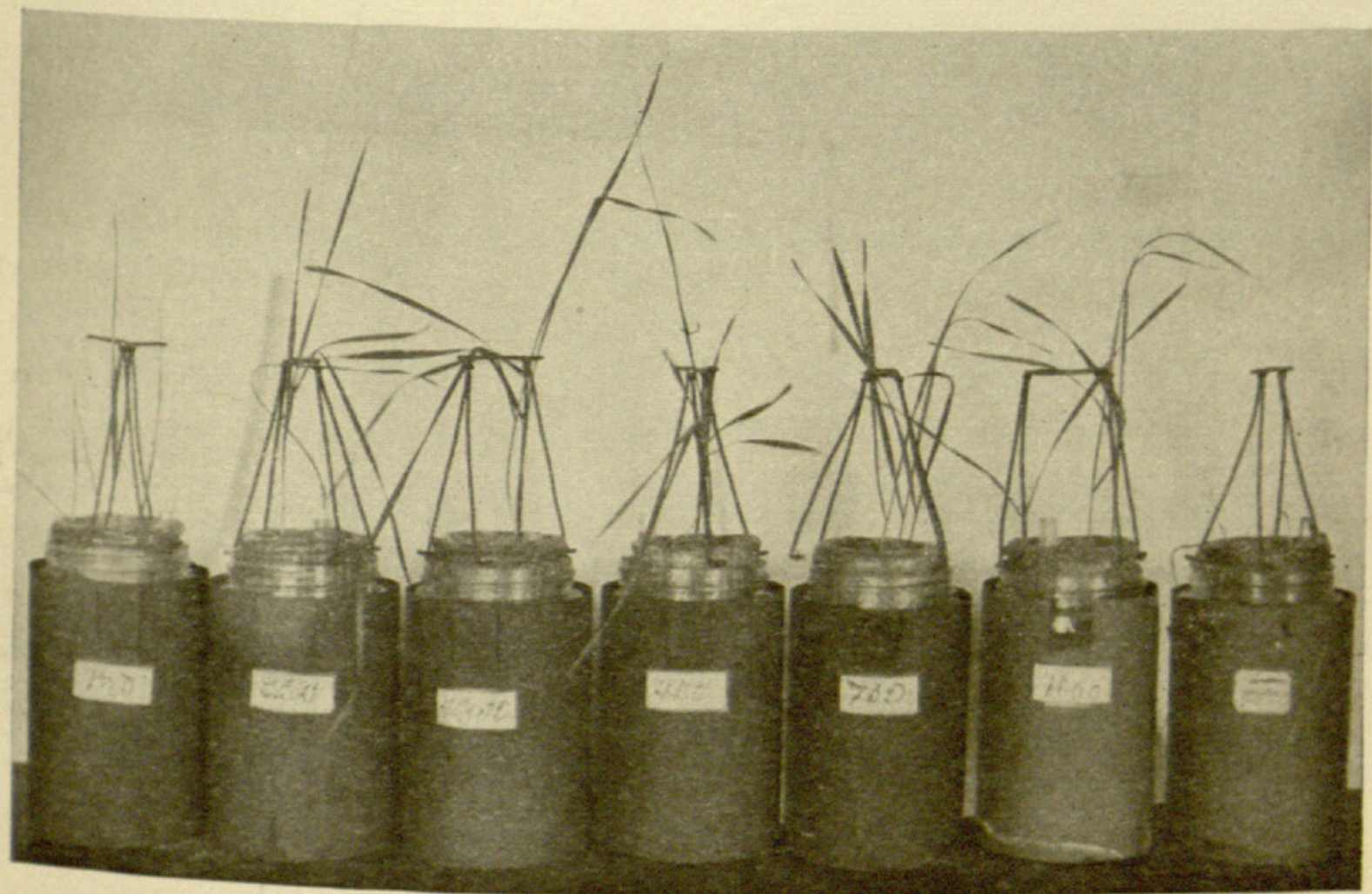

FIG. I.-Tolerance of wheat seedlings to solutions of $\mathrm{Na}_{2} \mathrm{HPO}_{4}$; roots immersed in the solution: 1 , distilled water; 2 , soil extract $(2: \mathrm{I}) ; 3$, extract +300 ppm $\mathrm{P}_{2} \mathrm{O}_{5}$; 4 , same $+500^{\mathrm{ppm}} ; 5$, same $+700^{\mathrm{ppm}} ; 6$, same $+1000^{\mathrm{ppm}} ; 7$, same $+2000^{\mathrm{ppm}}$.

same kind of soil, making it up to the proper moisture content, and watering the plants with solutions of the same salts, of concentrations equal to and higher than the maximum tolerance determined for the extract by cultures.

$\mathrm{Na}_{2} \mathrm{HPO}_{4}, \mathrm{KCl}$, and $\mathrm{NaNO}_{3}$ were selected for use, separately and in various combinations. Some of the results obtained with the phosphate salt are given here. The extract was prepared by mixing a known quantity of air-dry soil with twice its weight of distilled water, leaving the mixture, with occasional stirring, for 48 hours, and filtering off the liquid. Portions

'The method devised by the Bureau of Soils, U. S. Dept. Agric. (see Bull. 23 and others of the Bureau). 
of this extract were then made up to contain $300,500,700,1000$, and 2000 parts per million of $\mathrm{P}_{2} \mathrm{O}_{5}$ in the form of $\mathrm{Na}_{2} \mathrm{HPO}_{4}$.

The plants were set in small wire baskets (paraffined along the sides only) containing some sterile quartz sand, and the baskets placed in jars containing the proper extract, as shown in figs. $I$ and 2. One set of plants was prepared with the roots immersed in the liquid, another with roots remaining in the sand The cultures were aerated by pouring the liquid from one jar into another and the losses by evaporation and transpiration were made up daily with the corresponding extracts. The effect is seen

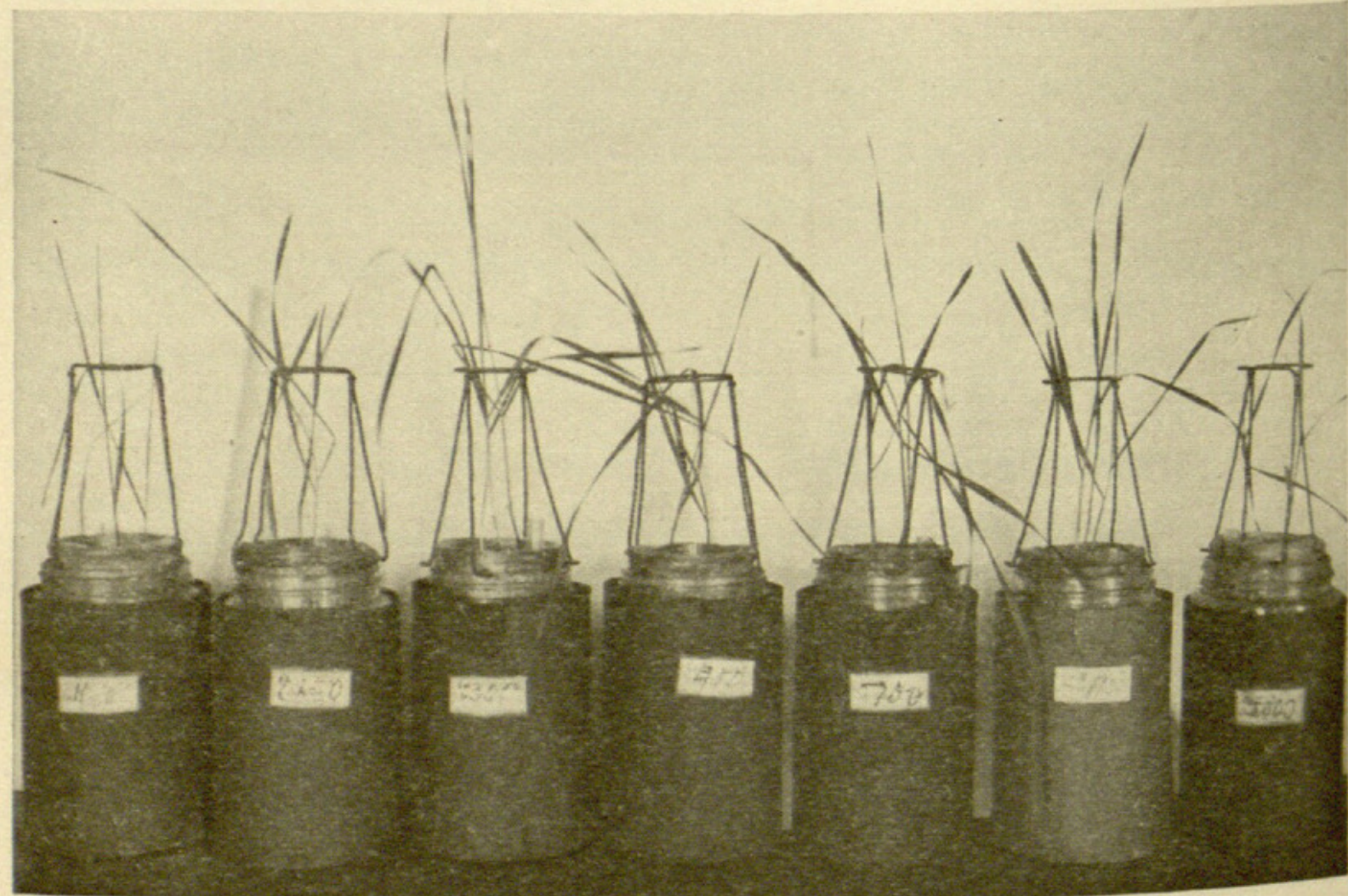

FIG. 2.- Tolerance of wheat seedlings to solutions of $\mathrm{Na}_{2} \mathrm{HPO}_{4}$ in soil extract; roots kept in sand of the baskets: $I$, distilled water; 2 , soil extract (2 water: I soil);

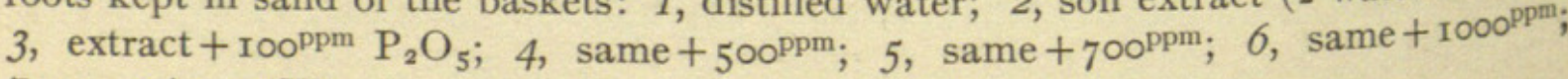
7 , same $+2000^{\mathrm{ppm}}$.

from the photographs. Up to the $700^{\mathrm{ppm} 2}$ concentration there was no marked difference between the two lots of plants. But while $700^{\mathrm{ppm}}$ immersed plants had a decidedly sickly appearance, the non-immersed ones looked quite healthy even in the $1000^{\mathrm{ppm}}$ extract. The $2000^{\mathrm{ppm}}$ of the non-immersed lot kept on struggling along even after three weeks from planting; while the immersed ones were killed in less than ten days.

It is thus seen that even the sterile quartz enables the plants to resist higher concentrations of the phosphates. The actual amount of salt

${ }_{2}^{2}$ Parts per million. 
absorbed by the quartz was found to be about ro per cent. in ppm of the original quantity. It was determined in the following way. The basket with the sand was removed from the jar. A sample was immediately taken to determine the water content; at the same time another portion of the same sand was washed with distilled water in ten successive portions. The washings were then evaporated to the volume calculated from the results obtained with the first sample (per centage of moisture in the sand) and the phosphates in the liquid determined. The phosphates in the extract contained in the jar from which the basket was removed were also determined,

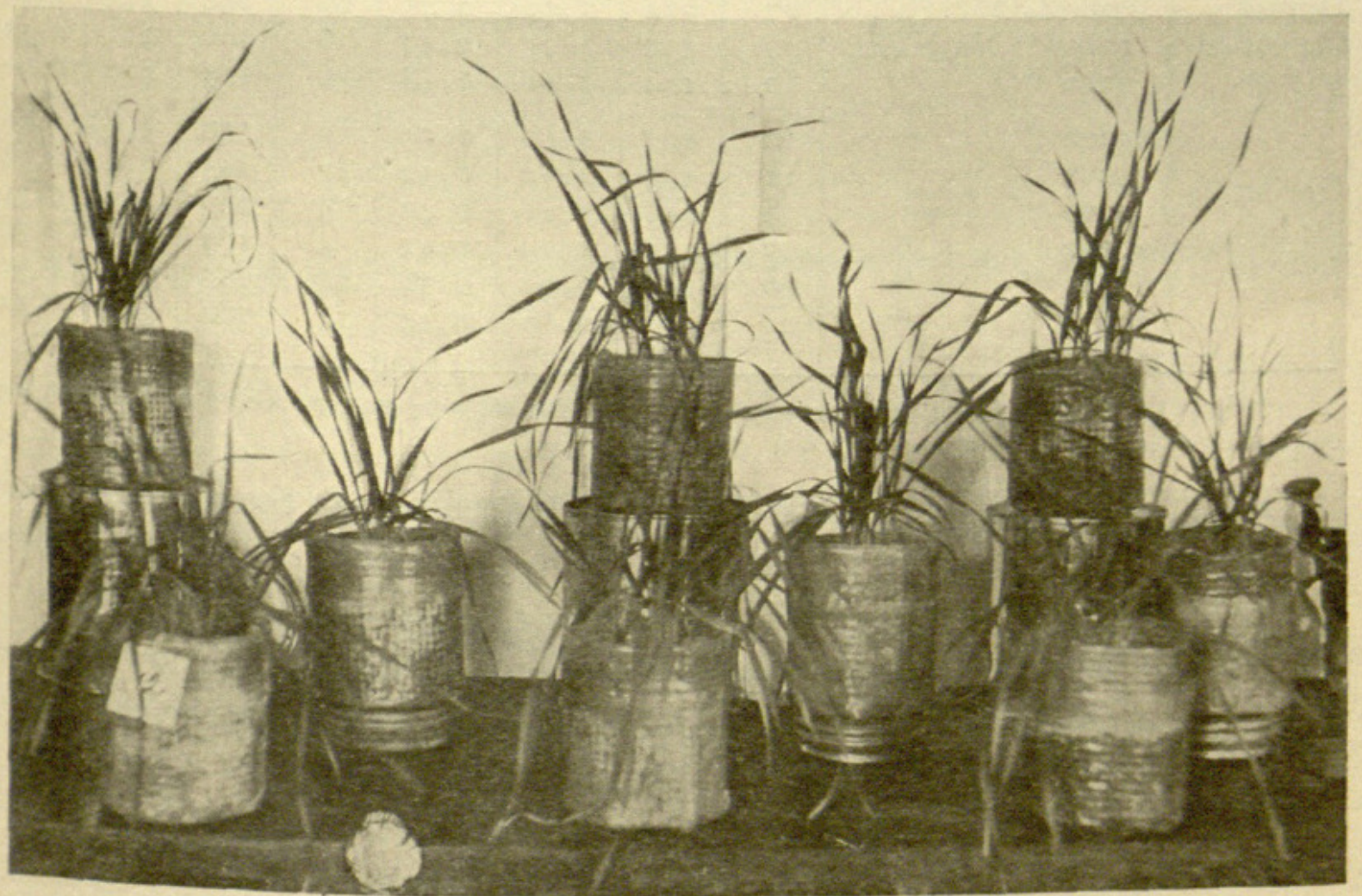

FIG. 3.-Wheat seedlings in unmanured soil: upper row, left to right, all watered for last 7 days with $\mathrm{P}_{2} \mathrm{O}_{5}$ solution $\left(I, 10,000^{\mathrm{ppm}} ; 2,7000^{\mathrm{ppm}} ; 3,6000^{\mathrm{ppm}}\right)$; middle row, left to right, watered in same way (I, $\left.5000^{\mathrm{ppm}} ; 2,4000^{\mathrm{ppm}} ; 3,3000^{\mathrm{ppm}}\right)$;

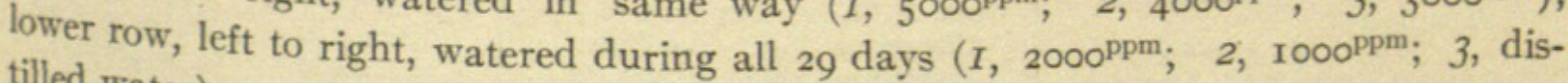
tilled water).

and the difference between these determinations taken as the amount of phosphates absorbed by the sand.

The tolerance of the wheat seedlings to concentrations of the phosphate was very much increased when grown in the soil proper, as shown in fig. 3 . Even concentrations of $6000^{\mathrm{ppm}}$, as seen also from the columns of "green" and "air-dry" weights in Table A, had no injurious effect on the plants. Only a concentration of $10,000^{\mathrm{ppm}}$ was distinctly harmful.

The addition to the soil of unsterilized, fairly well-rotted cow manure, 
in the ratio of $1: 250$, enabled the plants to resist still higher concentrations, as seen from the same table.

TABLE A

COMPARATIVE RESUlTS AT THE END OF 30 DAYS

\begin{tabular}{|c|c|c|c|c|c|c|c|c|c|c|}
\hline & \multirow{2}{*}{\multicolumn{2}{|c|}{ TREATMENT }} & \multicolumn{4}{|c|}{ SOIL NOT MANURED } & \multicolumn{4}{|c|}{ MANURE NOT STERILIZED } \\
\hline & & & $\frac{\text { gु }}{\text { के }}$ & 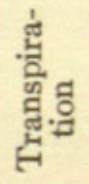 & ङ & 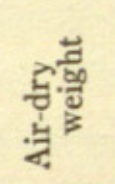 & 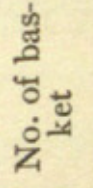 & 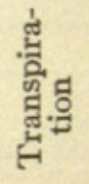 & 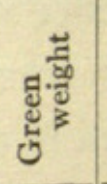 & 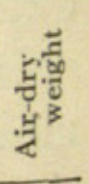 \\
\hline $\begin{array}{l}\text { During } \\
\text { the entire } \\
30 \text { days }\end{array}$ & $\left\{\begin{array}{c}\text { Dist. } \mathrm{H}_{2} \mathrm{C} \\
1000^{\mathrm{ppm}} \\
2000 \text { " }\end{array}\right.$ & ${ }_{2} \mathrm{HPO}_{4}$ & $\begin{array}{r}27 \\
9 \\
12\end{array}$ & $\begin{array}{l}224 \\
152 \\
146\end{array}$ & $\begin{array}{l}3.00 \\
3.05 \\
3.00\end{array}$ & $\begin{array}{l}0.4 \mathrm{I} \\
0.45 \\
0.48\end{array}$ & $\begin{array}{r}16 \\
6 \\
18\end{array}$ & $\begin{array}{l}220 \\
160 \\
143\end{array}$ & $\begin{array}{l}3.5 \\
3.8 \\
4.0\end{array}$ & $\begin{array}{l}0.48 \\
0.5^{\circ} \\
0.60\end{array}$ \\
\hline $\begin{array}{l}\text { During } \\
\text { the last } \\
7 \text { days }\end{array}$ & 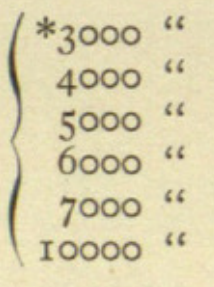 & $\begin{array}{l}\text { "6 } \\
\text { "6 } \\
\text { "6 } \\
\text { "6 }\end{array}$ & $\begin{array}{r}10 \\
\text { II } \\
8 \\
7 \\
26 \\
25\end{array}$ & $\begin{array}{l}\text { I } 22 \\
\text { I } 35 \\
\text { I } 86 \\
\text { I } 78 \\
\text { I90 } \\
\text { I80 }\end{array}$ & $\begin{array}{l}3.20 \\
3.10 \\
3.10 \\
3.20 \\
2.90 \\
2.20\end{array}$ & $\begin{array}{l}0.54 \\
0.42 \\
0.42 \\
0.41 \\
0.38 \\
0.34\end{array}$ & $\begin{array}{r}13 \\
\text { I } 7 \\
5 \\
4 \\
15 \\
\text { I4 }\end{array}$ & $\begin{array}{l}\text { I } 38 \\
\text { I } 43 \\
\text { I } 80 \\
\text { I } 87 \\
\text { I95 } \\
\text { I84 }\end{array}$ & $\begin{array}{l}3 \cdot 55 \\
3 \cdot 5 \\
3 \cdot 5 \\
3.8 \\
3 \cdot 7 \\
3 \cdot 5\end{array}$ & $\begin{array}{l}0.5^{6} \\
0.5^{8} \\
0.55 \\
0.5^{8} \\
0.54 \\
0.5^{2}\end{array}$ \\
\hline
\end{tabular}

* Up to the last 7 days the even numbers of the following set were watered with a $2000^{\mathrm{ppm}}$ and the odd ones with a $1000^{\mathrm{ppm}}$ solution.

That the increased tolerance of the wheat seedlings to the concentration of the salt is actually due, at least to a very great extent, to the absorptive power of the soil is sustained by the following facts:

(I) The analytical studies show that the soil actually removes large quantities of the phosphoric acid from the solution, as seen by the following table:

\section{TABLE B}

ABSORPTION OF PHOSPHATE BY THE SOIL

\begin{tabular}{|c|c|c|c|c|c|}
\hline \multirow{2}{*}{$\begin{array}{l}\text { P.P.M. OF } \mathrm{P}_{2} \mathrm{O}_{5} \\
\text { IN ORIGINAL } \\
\text { SOLUTION }\end{array}$} & \multirow[b]{2}{*}{ METHOD } & \multicolumn{2}{|c|}{ SOIL NOT MANURED } & \multicolumn{2}{|c|}{ SOIL MANURED } \\
\hline & & $\begin{array}{l}\mathrm{Ppm} . \mathrm{P}_{2} \mathrm{O}_{5} \text { in } \\
\text { filtrate or } \\
\text { percolate }\end{array}$ & $\begin{array}{c}\text { Per cent. of } \mathrm{P}_{2} \mathrm{O}_{5} \\
\text { in Ppm. } \\
\text { absorbed }\end{array}$ & $\begin{array}{l}\mathrm{Ppm} . \mathrm{P}_{2} \mathrm{O}_{5} \text { in } \\
\text { filtrate or } \\
\text { percolate }\end{array}$ & $\begin{array}{l}\text { Per cent. of } \\
\mathrm{P}_{2} \mathrm{O}_{5} \text { in } \mathrm{Ppm} \text {. } \\
\text { absorbed }\end{array}$ \\
\hline $\begin{array}{l}1000 \\
1000 \\
2000 \\
2000\end{array}$ & $\begin{array}{l}\mathrm{A} * \\
\mathrm{~B} \dagger \\
\mathrm{A} * \\
\mathrm{~B} \dagger\end{array}$ & $\begin{array}{r}795 \\
728 \\
\text { I } 740 \\
1690\end{array}$ & $\begin{array}{l}20.5 \\
27.2 \\
26.0 \\
31.0\end{array}$ & $\begin{array}{r}745 \\
698 \\
1700 \\
1674\end{array}$ & $\begin{array}{l}25.5 \\
30.2 \\
30.0 \\
32.6\end{array}$ \\
\hline
\end{tabular}

* Method A. $-25^{\mathrm{gm}}$ of the soil mixed with $50^{\mathrm{cc}}$ of the corresponding solution left with occasiona shaking for 48 hours, filtered and the filtrate analyzed for phosphates.

$\dagger$ METHon B. $-200^{\mathrm{gm}}$ of the soil placed in a wire basket (paraffined along the sides only) and $400^{\mathrm{cc}}$ of the corresponding solution allowed to percolate through the soil; the percolate analyzed for phosphates.

(2) In the case of a nitrate salt, where the absorption is a negligible quantity, the tolerance of the immersed and non-immersed plants, as will 
be more fully demonstrated in a later communication, is practically the same.

(3) The tolerance increases with the increase of the absorptive power; both factors being lower in the quartz, higher in the unmanured soil, and still higher in the manured soil.-JOSEPH Rosen and CHARLES HELLER, Agricultural College, Michigan. 


\section{$2 \mathrm{BHL}$ Biodiversity Heritage Library}

Rosen, Joseph and Heller, Charles. 1908. "The Absorptive Power of a Cultivated Soil." Botanical gazette 46(3), 224-229.

https://doi.org/10.1086/329699.

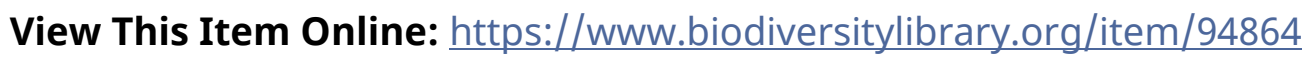

DOI: https://doi.org/10.1086/329699

Permalink: https://www.biodiversitylibrary.org/partpdf/223348

\section{Holding Institution}

Missouri Botanical Garden, Peter H. Raven Library

\section{Sponsored by}

Missouri Botanical Garden

\section{Copyright \& Reuse}

Copyright Status: Public domain. The BHL considers that this work is no longer under copyright protection.

This document was created from content at the Biodiversity Heritage Library, the world's largest open access digital library for biodiversity literature and archives. Visit BHL at https://www.biodiversitylibrary.org. 